\title{
食事性肥満ラットにおけるタンパク質代謝に 対する制限食の影響
}

\author{
尾井百合子, 奥 田豊子 \\ 三好弘子, 小石秀夫 \\ 大阪市立大学生活科学部
}

\author{
Effect of Restricted Diet on Protein Metabolism in \\ Rats Made Obese by High-Fat Diet \\ Yuriko OI, Toyoko OKUDA, Hiroko MIYOSHI \\ and Hideo KOISHI \\ Faculty of Science of Living, Osaka City University, Osaka 558
}

\begin{abstract}
Nippon Eiyō Shokuryō Gakkaishi (J. Jpn. Soc. Nutr. Food Sci.) 40, 27 34 (1987)
The effects of a restricted diet on protein metabolism were studied in rats made obese by a diet containing $30 \%$ fat. Three restricted diets, all containing 5\% fat, were a high-protein diet (HPD; 50 $\%$ casein), a standard-protein diet (SPD; $25 \%$ casein), and a low-protein diet (LPD; $5 \%$ casein). The intake of feed was restricted to $5 \mathrm{~g}$ per day. Two weeks later, every group of rats that had eaten one of the restricted diets lost about $100 \mathrm{~g}$ in body weight; the level of protein intake made no difference in the weight decrease. The nitrogen balance of the HPD and SPD rats was positive; that of the LPD was strongly negative. The amount of moisture in the carcass in the restricted-diet groups was similar, but there were significant differences in the percentage of lipids and protein. The percentage of protein was the highest and that of lipids was the lowest in the carcasses of HPD rats. These results suggest that the amount of protein in a restricted diet is important to maintain protein metabolism in obese rats.
\end{abstract}

(Received June 19, 1986)

肥满の治療として，摂取ェネルギーの制限を行ならと きそと摄取タンパク質レベルの違いが全身のタンパク 質代謝回転に大きな影響を与えることが報告されてい る。Garlick ら1)は、エネルギー制限時にタンパク質レ ベルを種々に変えたとき，代謝プールへのアミ/窒素の

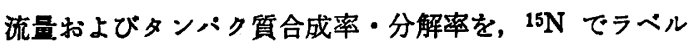
したグリシンを用いて検討した。エネルギー制限時の代 謝ブールヘのアミノ窒素の流量およびタンパク合成率 は，その摂取タンパク質レベルに比例し，エネルギーを 制限してもタンパク質の摄取量が十分であれば，生体の タンパク質代謝回転は通常の食事を摄取しているときと 変わらなかった。また絶食と半飢餓療法 (PSMF：protein sparing modified fast) のときの生体のタンパク質 代謝回転についての報告では228，絶食では体タンパク 質の崩壊がみられたが，PSMF では正常に維持されてい

宁558 大阪市住吉区杉本 3-3-138
ることが示された。

このように，生体に悪影響を及ぼさずに体重を減少さ せるには,タンパク質のレベルは非常に重要である4) 6)。 したがってタンパク質の摂取量が肥满の食事療法の重要 なポイントとなる。そこで本研究は, 雄の SpragueDawley 系ラットを用いて高脂肪食 (30\% 脂肪食) を投 与することにより, 食事性肥满ラットをつくり,タンハ ク質レペルの異なる制限食を与えたとき, 窒素出納値と 体組成（水分, タンパク質, 脂肪の割合) にどのように 影響するかを検討した。

\section{実 験 方 法}

3 週龄の Sprague-Dawley 系の雄ラットを 1 週間, 固 形飼料で予備飼育し，体重が $70 \sim 80 \mathrm{~g}$ になった後，タ ンパク質レペルを $25 \%$ に統一して，30\% 脂肪食 $(30 \%$ Fat 群) と，5\% 脂肪食 (5\%Fat 群) の 2 群で 12 週間 飼育した。12 週後，30\%Fat 群は 5\%Fat 群よりも体重 
が有意に増加したので, この時点で $30 \% \mathrm{Fat}$ 群を 4 群に 分け，1群には $30 \%$ Fat 食をひきつつき自由に与え, 残 りの 3 群は脂肪を $5 \%$ と一定にし，さらに飼料のタンハ ク質量を $50 \%$ カゼイン食 (HPD 群)，25\% カゼイン食 (SPD 群) および $5 \%$ カゼイン食(LPD 群)の 3 種とし, これを 1 日 $5 \mathrm{~g}$ に制限して投与した。同時に $5 \%$ Fat 群 もひきつつき 2 週間飼育した。実験に用いた飼料組成は Table 1 のとおりである。

各実験食の最後の 3 日間, ラットを代謝ヶージス れ，4 日目の朝，ラットをケージより除き，3 日間の尿 と䔬を採取し，これらとあわせて飼料の窒素量を測定 し, 窒素出納値を算出した。窒素の定量はセミミクロキ ルダール法によって行なった。各ラットについては, エ ーテル麻酔下で解剖を行ない, 腹部大動脈から採血し, 各蔵器を取り出した後, 手, 足, 尾および皮を除いてカ ーカスとした。

血液については, ヘマトクリット值は高速遠心器によ る毛細管法7で測定し，へモグロビン濃度をシアンメト ヘモグロビン法8)で比色定量した後，血漿を分離した。 血將成分について，総タンパク質濃度はビューレット

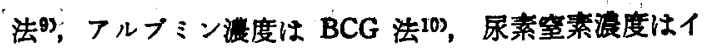
ンドフェノール法11により測定を行なった。また総コレ

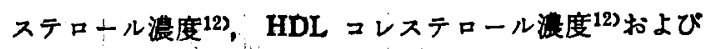
トリリグリセリド港度 ${ }^{139}$ は酵素法で測定した。

カーカスは,ひき肉機で粉砕し均一にした。カーカス の一部之肝臓は凍結乾燥し, その乾燥重量から水分を算 出した。また窒素量をセミミクロキルダール法で定量 し, 脂質の抽出を Folch 法14)により行ない, 重量法で 脂質含量を測定した。

\section{結果および考察}

\section{1. 流脂肪食肥满ラットの作成}

本研究では, 高脂肪食を用いて肥満動物を作り, タン ハク質レペルの違う制限食が体重減少とタンパク質代謝 へどのように影響を与えるか, 検討を行なった。

カフェテリア食肥満ラット 15)16)に絶食や食事制限を行 ない, その脂肪細胞の特徵についての検討がなされてい る。一方, 高脂肪食 (60\% 脂肪 食) ${ }^{17}$ ) と高炭水化物食 (60\% 炭水化物食) ${ }^{17)}$ による糖代謝への影響についての 研究も行なわれてきている18)19)。筆者らも初め $60 \%$ 脂

Table 1. Diet composition.

\begin{tabular}{|c|c|c|c|c|c|}
\hline & \multicolumn{2}{|c|}{ ad libitum feeding $\mathrm{A}$} & \multicolumn{3}{|c|}{ Restricted feeding ${ }^{B}$} \\
\hline & $5 \%$ Fat & $30 \%$ Fat & HPD & SPD & LPD \\
\hline Casein (\%) & 25 & 25 & 50 & 25 & 5 \\
\hline $\mathrm{Crisco}^{\mathrm{C}}(\%)$ & 5 & 30 & 5 & 5 & 5 \\
\hline Vitamin mixture ${ }^{\mathrm{D}}(\%)$ & 1.7 & 1.7 & 1.7 & 1.7 & 1.7 \\
\hline Mineral mixture $(\%)$ & 5 & 5 & 5 & 5 & 5 \\
\hline Cellulose (\%) & 4 & 4 & 4 & 4 & 4 \\
\hline Sugar $(\%)$ & 30 & 30 & 30 & 30 & 30 \\
\hline Cornstarch (\%) & 29.3 & 4.3 & 4.3 & 29.3 & 49.3 \\
\hline Energy $(\mathrm{kcal} / \mathrm{g})$ & 3.82 & 5.07 & 3.82 & 3.82 & 3.82 \\
\hline Dose (g/day) & \multicolumn{2}{|c|}{ (ad lib.) } & 5 & 5 & 5 \\
\hline Protein intake $(g)$ & & & 2.5 & 1.25 & 0.25 \\
\hline Energy intake (kcal) & & & 19.1 & 19.1 & 19.1 \\
\hline
\end{tabular}

A Rats were fed on a $5 \%$ or $30 \%$ fat diets for 14 weeks.

B Rats were fed on $30 \%$ fat diet for 12 weeks, and then on a high-protein, standard-protein, or lowprotein diet (HPD, SPD and LPD, respectively) for two weeks.

c Hydrogenated shortening from Procter and Gamble, Cincinnati, Ohio.

D Purchased from Oriental Yeast Co., Tokyo.

Vitamin mixture $(100 \mathrm{~g})$ contained vitamin A-acetate, $50,000 \mathrm{IU}$; vitamin $\mathrm{D}_{8}, 10,000 \mathrm{IU}$; thiamine$\mathrm{HCl}, 120 \mathrm{mg}$; riboflavin, $400 \mathrm{mg}$; pyridoxine- $\mathrm{HCl}, 80 \mathrm{mg}$; vitamin $\mathrm{B}_{12}, 0.05 \mathrm{mg}$; vitamin C, $3,000 \mathrm{mg}$; vitamin E-acetate, $500 \mathrm{mg}$; vitamin $\mathrm{K}_{3}, 520 \mathrm{mg}$; biotin, $2 \mathrm{mg}$; folic acid, $200 \mathrm{mg}$; Ca-pantothenate, $\$$ $500 \mathrm{mg}$; p-amino benzoic acid, $500 \mathrm{mg}$; nicotinic acid, $600 \mathrm{mg}$; inositol, $600 \mathrm{mg}$; and choline chloride, $20,000 \mathrm{mg}$.

Mineral mixture $\left(100 \mathrm{~g}\right.$ ) contained $\mathrm{CaH}_{4}\left(\mathrm{PO}_{4}\right)_{2} \cdot \mathrm{H}_{2} \mathrm{O}, 14.56 \mathrm{~g} ; \mathrm{KH}_{2} \mathrm{PO}_{4}, 25.72 \mathrm{~g} ; \mathrm{NaH}_{2} \mathrm{PO}_{4} \cdot \mathrm{H}_{2} \mathrm{O} 9.35 \mathrm{~g}$; $\mathrm{NaCl}, 4.66 \mathrm{~g}$; Ca-lactate, $35.09 \mathrm{~g}$; Fe-citrate, $3.18 \mathrm{~g} ; \mathrm{MgSO}_{4} \cdot 3 \mathrm{H}_{2} \mathrm{O}, 7.17 \mathrm{~g} ; \mathrm{ZnCO}_{3}, 0.11 \mathrm{~g} ; \mathrm{MnSO}_{4}$, $0.12 \mathrm{~g} ; \mathrm{CuSO}_{4}, 0.03 \mathrm{~g}$; and $\mathrm{KI}, 0.01 \mathrm{~g}$. 
肪食の投与を試みたが，摄食量が少なく体重増加を認め なかった。それに比へで，30\% 脂肪食では対照群より 一有意な体重增加を示した。よって高脂肪食肥満ラット の作成のために， $30 \%$ 脂肪食を用いることにした。

\section{2. 体血と飼料提食量}

Fig.1(A) に体重の变化を示した。Table 2 に示した よ5K, 30\%Fat 群の体重增加量は 5\%Fat 群よりも有
意に高くなった。両群のエネルギー効率に差はないが, 飼料中の脂肪含量が 30\%Fat 群のほうが高いため, 摄取 エネルギー量が有意依くなり，30\%Fat 群で $5 \%$ Fat 群より有意に体重が增加したものと考えられる。

このように体重増加を示した 30\%Fat 群に対し，タン バク質量の異なる制限食を 2 週間投与すると, 体重は約 $100 \mathrm{~g}$ 前後急激に減少した(Fig.1(B))。Walks ら ${ }^{16)}$ は,

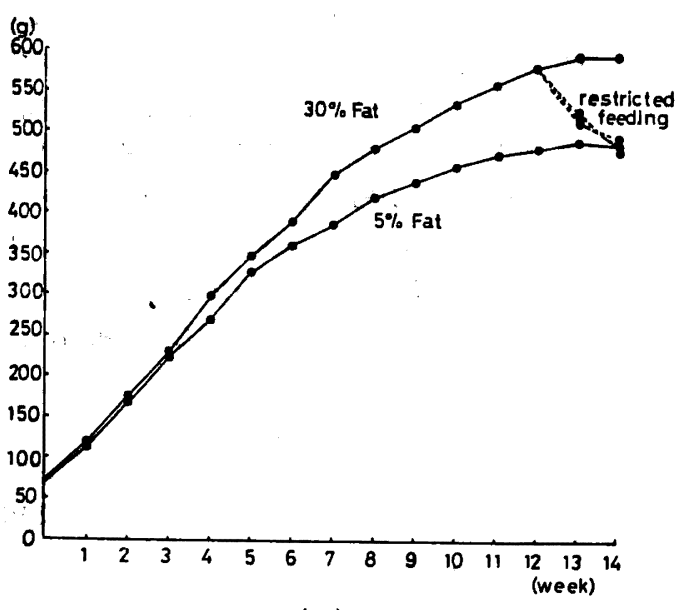

(A)

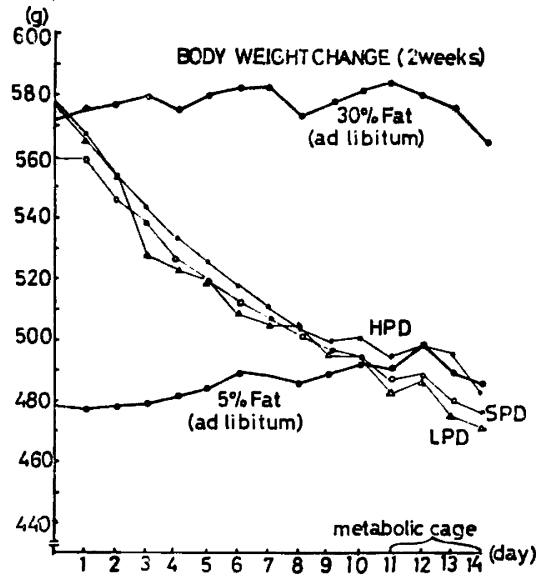

(B)

Fig. 1. Body weight change.

(A) 1-14 weeks: The effect of ad libitum feeding (5\% Fat, 30\% Fat) on body weight changes (1-14 weeks). Dotted line (restricted feeding) shows HPD, SPD and LPD in (B).

(B) 2 weeks: The effect of restricted feeding ( HPD, O SPD, $\triangle$ LPD) and ad libitum feeding ( $5 \%$ Fat, $30 \%$ Fat) on body weight changes (12-14 weeks).

Table 2. Body weight and diet consumption (1-12 weeks).

\begin{tabular}{|c|c|c|}
\hline & $5 \%$ Fat & $30 \%$ Fat \\
\hline & $n=3$ & $n=17$ \\
\hline Body weight on 12 weeks (g) & $\mathrm{A} 482 \pm 10^{\mathrm{aB}}$ & $581 \pm 11^{\mathrm{b}}$ \\
\hline Body weight change (g/day) $\mathrm{C}$ & $4.85 \pm 0.10^{\mathrm{a}}$ & $6.02 \pm 0.12^{b}$ \\
\hline \multicolumn{3}{|l|}{ Diet consumption } \\
\hline Intake (g/day) & $20.8 \pm 0.5^{a}$ & $18.3 \pm 0.4^{b}$ \\
\hline Protein (g/day) & $5.2 \pm 0.1^{\mathrm{a}}$ & $4.6 \pm 0.1 \mathrm{a}$ \\
\hline Fat (g/day) & $1.0 \pm 0.1 \mathrm{a}$ & $5.6 \pm 0.1^{b}$ \\
\hline Energy（kcal/day） & $79.4 \pm 1.8^{\mathrm{a}}$ & $93.1 \pm 1.4^{b}$ \\
\hline \multicolumn{3}{|l|}{ Efficiency } \\
\hline Protein (B.W. g/g) & $0.94 \pm 0.08 \mathrm{a}$ & $1.31 \pm 0.16^{\mathrm{a}}$ \\
\hline Fat (B.W. g/g) & $4.70 \pm 0.03^{a}$ & $1.09 \pm 0.01^{b}$ \\
\hline Energy (B.W. $\mathrm{g} / 100 \mathrm{kcal}$ ) & $6.2 \pm 0.1 \mathrm{a}$ & $6.5 \pm 0.3^{a}$ \\
\hline Food (B.W. $g / g$ ) & $0.24 \pm 0 \mathrm{a}$ & $0.33 \pm 0.01^{b}$ \\
\hline
\end{tabular}

$A$ Values are means $\pm S E$.

B abMeans in the same row sharing a common superscript letter are not significantly different $(p<0.05)$.

c (Body weight on 12 weeks-initial body weight)/12 weeks. 
カフェテリア食肥満ラットを 10 日間絶食にすると, 約 $120 \mathrm{~g}$ 前後減少し、 コントロール群とほ注同じ体重にな ったとしている。このよらに食事制限をすることによっ て体重は減少するわけであるが，このラットにコントロ 一ル群と同じ飼料を同じ量だけ再び拄取させると、 ニン トロール群よりも体重は增加することをみた ${ }^{16) 。 し た か ゙ ~}$ って一度肥満したラットは，その摄食量を正常ラットよ り少なくしないと，再び肥満する傾向を示すということ がいえる18)。

Table 3 に第 12 週より 14 週までの間の各群の飼料 摂取量と体重変化を示した。制限食の飼料攝食量は $5 \mathrm{~g} /$ 日であり,摂取タンパク質量は HPD 群 $2.5 \mathrm{~g} /$ 日, SPD 群 $1.25 \mathrm{~g}$ /日, LPD 群 $0.25 \mathrm{~g}$ /日となり, 摂取エネルギ 一は 30\%Fat 群のときの約 4 分の 1 であった。このよう な制限食の摄取タンバク質量の違いは，体重減少に対し てはほとんど影響しなかった。

\section{3. 䆟素出㘨值}

Table 4 飞第 14 週の最後の 3 日間飞測定した値を示 した。5\%Fat 群の 3 日間の窒素出納値は $(+21 \pm 1 \mathrm{mg}$ N) よりも $30 \%$ Fat 群 $(+120 \pm 20 \mathrm{mgN})$ のほらが有意 に高くなった。制限食では 3 日間の尿中排泄窒素量が $\mathrm{HPD}$ 群 $(838 \pm 29 \mathrm{mgN})$ と SPD 群 $(396 \pm 24 \mathrm{mgN})$ で, その摄取窒素レベルに応して尿中窒素が減少したのに対 し, LPD 群では摄取窒素が非常に少ない $(94 \mathrm{mgN})$ に もかかわらず，尿中窒素量は SPD 群とほほ等しい值 $(327 \pm 41 \mathrm{mgN})$ になった。摂取窒素量以上の窒素排泄 は, 体タンバク質の崩壊を意味しこれは一部内因性の 窒素代謝を反映していると思われる。その結果，制限食 の窒素出納值は HPD 群 $(+84 \pm 19 \mathrm{mgN})$ と SPD 群 $(+43 \pm 20 \mathrm{mgN})$ で正の出納を維持したが，LPD 群 $(-262 \pm 41 \mathrm{mgN})$ では著しい負となった。

このよらにエネルギー制限を行なった場合，掑取タン

Table 3. Body weight and diet consumption (12-14 weeks).

\begin{tabular}{|c|c|c|c|c|c|}
\hline & $5 \%$ Fat & $30 \%$ Fat & HPD & SPD & LPD \\
\hline & $n=3$ & $n=5$ & $n=4$ & $n=4$ & $n=4$ \\
\hline Body weight $(g)$ & $\mathrm{A} 492 \pm 2^{\mathrm{aB}}$ & $575 \pm 32^{b}$ & $496 \pm 10^{\mathrm{a}}$ & $486 \pm 22^{\mathrm{a}}$ & $481 \pm 12^{a}$ \\
\hline Body weight change ( $g /$ day) & & & $-6.5 \pm 2.0^{\mathrm{a}}$ & $-7.1 \pm 0.4^{\mathrm{a}}$ & $-7.8 \pm 0.5^{2}$ \\
\hline $\begin{array}{l}\text { Body weight changec } \\
\qquad(\% / 14 \text { days })\end{array}$ & & & $-15 \pm 2^{\mathrm{a}}$ & $-17 \pm 1 \mathrm{a}$ & $-19 \pm 1 a$ \\
\hline Diet intake ( $g /$ day) & $18.3 \pm 1.4$ & $16.6 \pm 2.0$ & 5 & 5 & 5 \\
\hline Protein (g/day) & $4.6 \pm 0.3$ & $4.2 \pm 0.2$ & 2.5 & 1.25 & 0.25 \\
\hline Fat (g/day) & $0.9 \pm 0.1$ & $5.0 \pm 0.3$ & 0.25 & 0.25 & 0.25 \\
\hline Energy (kcal/day) & $69.7 \pm 5.5$ & $85.7 \pm 4.3$ & 19.1 & 19.1 & 19.1 \\
\hline
\end{tabular}

$A$ Values are means \pm SE.

B abMeans in the same row sharing a common superscript letter are not significantly different $(p<0.05)$.

C Body weight change (\%/14 days) : (body weight change for 14 days/body weight on 12 weeks) $\times 100$.

Table 4. Nitrogen balance (for 3 days).A

\begin{tabular}{|c|c|c|c|c|c|}
\hline & $5 \%$ Fat & $30 \%$ Fat & HPD & SPD & LPD \\
\hline & $n=3$ & $n=5$ & $n=4$ & $n=4$ & $n=4$ \\
\hline Food intake $(\mathrm{g})$ & $\mathrm{B} 46 \pm 6^{\mathrm{a}}$ & $\mathrm{c} 31 \pm 4^{a}$ & $15 \pm 0 \mathrm{~b}$ & $15 \pm 0 \mathrm{~b}$ & $15 \pm 0 b$ \\
\hline $\mathrm{N}$ intake $(\mathrm{mgN})$ & $1,463 \pm 211^{\mathrm{a}}$ & $988 \pm 116^{b}$ & $944 \pm 0^{b}$ & $472 \pm 0 c$ & $94 \pm 0 c$ \\
\hline Urinary $\mathrm{N}(\mathrm{mgN})$ & $1,385 \pm 211^{a}$ & $827 \pm 103^{b}$ & $838 \pm 29^{b}$ & $396 \pm 24^{c}$ & $327 \pm 41 \mathrm{c}$ \\
\hline Fecal N (mgN) & $60 \pm 2^{\mathrm{a}}$ & $41 \pm 6^{b}$ & $40 \pm 4^{b}$ & $33 \pm 5^{b}$ & $29 \pm 5^{b}$ \\
\hline $\mathrm{N}$-balance $(\mathrm{mgN})$ & $+21 \pm 1 \mathrm{a}$ & $+120 \pm 20^{b}$ & $+84 \pm 19 b$ & $+43 \pm 25^{\mathrm{ab}}$ & $-262 \pm 41 \mathrm{c}$ \\
\hline
\end{tabular}

A Rats in each group were separated to individual and domesticated in a metabolic cage and were measured nitrogen balance for last 3 days on 14 weeks.

$B$ Values are means $\pm \mathrm{SE}$.

C abcMeans in the same row sharing a common superscript letter are not significantly different $(p<0.05)$. 
ハク質レベルを変えても体重減少の程度に量いは認めら れなかったが，窒索出納值は大きな影警を受けていた。 5\%Fat 群と SPD 群は，飼料組成が同し（カぜイン

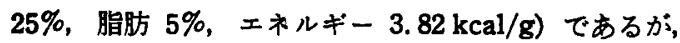
飼料の自由摂取と制限食投与の差のため，前者の飼料摂 取量が約 3 倍となった。それにもかかわらず，窒素出納 値には有意な差を示さなかった。Brown ら20)は，思春 期の肥满者に対してタンパク質は $1.5 \mathrm{~g} / \mathrm{kg} /$ ideal body weight とし，500 700 kcal のエネルギー制限食を投与 したとき，窒素出納は平衡を維持すると報告している。 一方, Fisler ら ${ }^{211}$ は, 大人の肥満男性に対してタンパク質

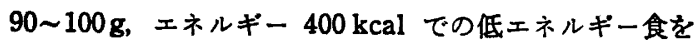
投与したとき，タンパク質の質の違いによる窒素出納値 への影䇾がなかったことを示している。本実験の SPD では，摄食量を減少させても摄取空素量が $472 \mathrm{mgN}$ と なり, 窒素出納値もほぼ等しく維持されていたので。こ の量がこれらのラットの必要量を満たしていたものと考 えられた。

\section{4. 体 組 成}

Table 5 に 14 週の終りに屠殺したラットのカーカス の組成を示した。カーカスの水分含量にはいずれの群間 にも差を認めなかった。カーカスの重量は 5\%Fat 群 $(328 \pm 3 \mathrm{~g})$ よりも $30 \%$ Fat 群 $(393 \pm 29 \mathrm{~g})$ が有意任多 かった。その重量の差は, 脂肪含量か：5\%Fat 群 $(60 \pm$ 3g）上りむ $30 \%$ Fat 群 $(103 \pm 10 \mathrm{~g})$ のほらが有意に多 いことからきている。一方, 制限食のカーカス重量は, 30 \%Fat 群に比較していずれの群も有意に少なくなった。 しかし制限群間に差はみられず，5\%Fat 群とほ注等し い值を示した。制限食において, HPD 群の脂肪含量か; $30 \%$ Fat 群に比へ有意に減少したが，タンパク質含量は
自由摄取群の $5 \%$ Fat 群および $30 \%$ Fat 群 とほぼ等し く維持された。SPD 群および LPD 群は，30\%Fat 群 に比へ脂肪含量（g）は減少の傾向を示したか，有意な 差ではなかった。

Walks ら ${ }^{16)}$ は，カフェテリア食肥満ラットにおける 体組成について，コントロール群に比べて水分およびタ ンパク質含量に違いがなかったが，脂肪含量は有意に高 いことを示している。また，そのラットを 10 日間絶食 にすると,カーカスの脂肪含量が減少してコントロール 群とほほ等しくなったとしている。一方，5\% カゼイン 食と $15 \%$ カゼイン食をそれぞれ自由摃取させたときの 体組成について，タンパク質含量はほほ等しい值であっ たが，脂肪含量は $5 \%$ カゼイン食が有意に高かったとい ら報告がある22)。このよらに食事制限を行ならことによ り，体脂肪は減少する。加えて，その飼料中に含まれる タンパク質含量によっても体脂肪量は影響されると考え られる。

さらにカーカスにおける水分，脂肪およびタンパク質 の占める割合についても検討した。体水分は $55 \%$ 前後 で各群間に有意差がなかった。体脂肪の割合は，5\%Fat 群に比へ 30\%Fat 群が有意に高くなっており（26.1土 $2.3 \%)$ ，明らかに食事性肥満の様相を示していた。また 30\%Fat 群で水分の割合も関係していたかもしれない が，脂肪の割合が高くなった結果としてタンパク質の占 める割合は 5\%Fat 群に比べて少なくなった。一方制限 食群では, HPD 群の脂肪 $(15.4 \pm 2.5 \%)$ が $30 \%$ Fat 群 よりも有意に少なくなり，そのかわりタンパク質の割合 が有意に高くなった。しかし，SPD 群および LPD群で は30\%Fat群に比べ，脂肪とタンパク質の割合に有意差 を認めなかった。

Table 5. Composition of carcass.A

\begin{tabular}{|c|c|c|c|c|c|}
\hline & $5 \%$ Fat & $30 \%$ Fat & HPD & SPD & LPD \\
\hline & $n=4$ & $n=5$ & $n=4$ & $n=4$ & $n=4$ \\
\hline Weight (g) & $\mathrm{B} 328 \pm 3^{\mathrm{a} C}$ & $393 \pm 29 b$ & $333 \pm 1^{\mathrm{a}}$ & $327 \pm 4^{\mathrm{a}}$ & $328 \pm 26^{a}$ \\
\hline Moisture (g) & $180 \pm 4^{a}$ & $198 \pm 17 \mathrm{a}$ & $186 \pm 16^{a}$ & $167 \pm 3^{\mathrm{a}}$ & $185 \pm 11 \mathrm{a}$ \\
\hline Lipid (g) & $60 \pm 3^{\mathrm{a}}$ & $103 \pm 10^{b}$ & $57 \pm 8^{a}$ & $83 \pm 6^{a b}$ & $75 \pm 5^{\mathrm{ab}}$ \\
\hline Protein (g) & $58 \pm 2^{a}$ & $60 \pm 7^{a}$ & $60 \pm 3^{a}$ & $47 \pm 1^{b}$ & $52 \pm 4^{2}$ \\
\hline Moisture (\%) & $55.0 \pm 1.2^{\mathrm{a}}$ & $50.2 \pm 0.8 \mathrm{a}$ & $56.0 \pm 3.9 \mathrm{a}$ & $51.7 \pm 2.9 \mathrm{a}$ & $56.3 \pm 2.2^{\mathrm{a}}$ \\
\hline Lipid (\%) & $18.3 \pm 0.8 \mathrm{a}$ & $26.1 \pm 2.3^{b}$ & $15.4 \pm 2.5^{\mathrm{a}}$ & $25.6 \pm 1.8 \mathrm{~b}$ & $23.2 \pm 1.7^{b}$ \\
\hline Protein (\%) & $17.8 \pm 0.6^{a}$ & $15.4 \pm 0.6^{b}$ & $18.6 \pm 0.8 \mathrm{a}$ & $14.6 \pm 1.1 \mathrm{~b}$ & $15.4 \pm 0.4^{b}$ \\
\hline Total (\%) & $91.4 \pm 3.2^{\mathrm{a}}$ & $91.7 \pm 3.3^{\mathrm{a}}$ & $91.3 \pm 2.5^{\mathrm{a}}$ & $92.1 \pm 2.3^{a}$ & $94.8 \pm 1.4^{a}$ \\
\hline
\end{tabular}

A After feeding experimental diet during 12 weeks, rats were given the each group of diets for 2 weeks and then measured moisture, lipid and protein content in carcasses.

$B$ Values are means $\pm \mathrm{SE}$.

c. abMeans in the same row sharing a common superscript letter are not significantly different $(p<0.05)$. 
Table 6. Liver composition.A

\begin{tabular}{|c|c|c|c|c|c|}
\hline & $5 \%$ Fat & $30 \%$ Fat & HPD & SPD & LPD \\
\hline & $n=3$ & $n=5$ & $n=4$ & $n=4$ & $n=4$ \\
\hline Weight (g) & B13. $2 \pm 1.3^{\mathrm{aCC}}$ & $14.4 \pm 1.2^{\mathrm{a}}$ & $11.3 \pm 0.7^{\mathrm{a}}$ & $10.9 \pm 0.6^{a}$ & $10.4 \pm 0.6^{2}$ \\
\hline Moisture (\%) & $65.1 \pm 2.0 \mathrm{a}$ & $63.2 \pm 0.8^{a}$ & $65.3 \pm 0.4^{\mathrm{a}}$ & $66.1 \pm 0.4^{\mathrm{a}}$ & $66.1 \pm 0.9^{a}$ \\
\hline Lipid (\%) & $12.8 \pm 0.9^{a}$ & $12.8 \pm 0.7 \mathrm{a}$ & $9.3 \pm 0.4^{b}$ & $8.3 \pm 0.5^{b c}$ & $6.9 \pm 0.5^{\mathrm{c}}$ \\
\hline Protein (g) & $2.3 \pm 0.3^{a}$ & $2.8 \pm 0.2^{\mathrm{a}}$ & $2.3 \pm 0.1^{\mathrm{ab}}$ & $2.1 \pm 0.1^{\mathrm{b}}$ & $1.8 \pm 0.1 \mathrm{c}$ \\
\hline Protein (\%) & $18.7 \pm 1.5^{\mathrm{a}}$ & $19.5 \pm 0.6^{\mathrm{a}}$ & $20.5 \pm 0.3^{\mathrm{a}}$ & $19.7 \pm 0.6^{a}$ & $17.7 \pm 0.7 \mathrm{a}$ \\
\hline Total (\%) & $97.0 \pm 1.9^{\mathrm{a}}$ & $95.5 \pm 0.8^{a}$ & $95.0 \pm 0.7 \mathrm{a}$ & $94.1 \pm 0.9 \mathrm{a}$ & $90.6 \pm 1.2^{\mathrm{a}}$ \\
\hline
\end{tabular}

${ }^{A}$ After feeding experimental diet during 12 weeks, rats were given the each group of diets for 2 weeks and were measured moisture, lipid and protein content in liver.

$B$ Values are means $\pm \mathrm{SE}$.

C abcMeans in the same row sharing a common superscript letter are not significantly different $(p<0.05)$.

このように 30\%Fat 食で肥満したラットに制限食を与 えると,カーカス重量は有意に減少したものの, その組 成に関しては HPD 群で脂肪の割合の減少を示したが, SPD 群および LPD 群では差がなく, 30\%Fat 群と同 様, 脂肪が多いといら体組成のままカーカスの重量が減 少したことが示された。また HPD 群においては, 体夕 ンパク質を保持したまま体脂肪が減少しており, 窒素出 納値の結果とともに，他の制限食群よりも肥満からの回 復に体タンパク質組成には影響を与えなかったという意 味で，最も効果があったと考えられる。肥満のヒトにつ いての報告122)では，通常の半分以下にェネルギーを制 限してもタンパク質さえ十分摂取していれば，代謝プー ルヘのアミノ窒素の流量およびタンパク質合成率・分解 率も通常のエネルギー摂取のときと変わりなかったとし ている。

以上のことから，肥満の治療にェネルギー制限を行な ら場合, 生体のタンパク質代謝を維持し, 体タンパク質 崩壊を起こさせずに体重を減少させなければならない が，そのためには高タンパク質食が必要であり，また体 重減少之同時に過剩の体脂肪を減少させるといら点から る摂取タンパク質レベルを高くする必要があると考えら れる。

\section{5. 肝 租 成}

肝組成を Table 6 に示した。肝臓重量は，5\%Fat 群 と30\%Fat群では有意差がなかったが，制限食において は減少傾向を示した。肝臟重量について，カフェテリフ 食肥満ラットではコントロール群よりも有意に高く、 た 10 日間の絶食により約半分に減少することが報告さ れている ${ }^{16)}$ 。肝䁍の水分の割合は，5\%Fat 群， $30 \%$ Fat 群および各制限食群いずれも $65 \%$ 前後で有意差がなか った。

脂肪の割合は， $5 \%$ Fat 群 $(12.8 \pm 0.9 \%)$ と $30 \% \mathrm{Fat}$
群 $(12.8 \pm 0.7 \%)$ は注ぼ等しい值を示し, 制限食ではい ずれも $5 \%$ Fat 群よりも有意に少なくなったが，摄取タ ンパク質レベルの少ないLPD 群 $(6.9 \pm 1.0 \%)$ が最も 少なくなった。タンバク質の割合は $5 \%$ Fat 群と $30 \%$ Fat 群および各制限食とも $19 \%$ 前後であり，有意差は なかった。しかしタンパク質含量でみれば，5\%Fat 群 に比へ，HPD 群では差を認めなかったが，SPD 群およ び LPD 群で低下した。このように肝臓重量は制限食に よってもほとんど減少しなかったが，肝組成に対する制 限食の影響がとくに LPD 群で, 脂肪含有量およびタン ハク質重量に顕著にみられた。

\section{6. 血液性状}

Table 7 に血液性状を示した。へマトクリット值と一 モグロピン浱度は，各群とも有意差がなく，制限食によ る違いも認めなかった。また総タンパク質濃度について も, SPD 群, LPD 群でやや低下傾向を示したものの, 各群とも有意差がなかった。アルブミン濃度は，5\%Fat 群と 30\%Fat群では有意差はみられず, 制限食でも HPD 群は前二者との間に有意差を認めなかった。しかし, SPD 群, LPD 群では有意に低下した。また尿素窒素濃 度についても制限食の HPD 群は，5\%Fat 群や 30\%Fat 群と有意差はみられなかったか，SPD 群，LPD 群は有 意な低下を示した。したがって HPD 群ではェネルギー 制限食であるにもかかわらず，血液性状に影艟しないだ けの十分な摂取タンパク質量であったと考えられる。総 コレステロール濩度, HDL コレステロール濼度および トリタリセリド浱度は, いずれも LPD 群で他の群より

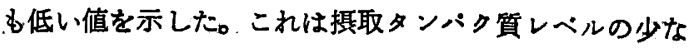
いことが血中脂質濃度にも影䇾を与えているものと考光 られる。

以上のようK，肥満ラッ、Kエネルギー制限食を与え たとき，25\%カゼインレベルあるいはそれ以下のタン 
Table 7. Blood status.

\begin{tabular}{|c|c|c|c|c|c|}
\hline & $5 \%$ Fat & $30 \%$ Fat & HPD & SPD & LPD \\
\hline & $n=3$ & $n=5$ & $n=4$ & $n=4$ & $n=4$ \\
\hline Ht (\%) & $\mathrm{A} 43,9 \pm 1.0^{\mathrm{aB}}$ & $42.3 \pm 1.4^{\mathrm{a}}$ & $45.0 \pm 0.8^{\mathrm{a}}$ & $43.8 \pm 0.5^{a}$ & $43.7 \pm 1.1^{\mathrm{a}}$ \\
\hline $\mathrm{Hb}(\mathrm{g} / \mathrm{dl})$ & $17.6 \pm 1.2^{\mathrm{a}}$ & $15.8 \pm 0.8^{\mathrm{a}}$ & $16.4 \pm 0.6^{\mathrm{a}}$ & $15.8 \pm 0.9^{a}$ & $15.8 \pm 0.6^{\mathrm{a}}$ \\
\hline \multicolumn{6}{|l|}{ Plasma } \\
\hline Total protein $(\mathrm{g} / \mathrm{dl})$ & $6.3 \pm 0.6 \mathrm{ab}$ & $7.0 \pm 0.3^{a}$ & $6.7 \pm 0.3^{\mathrm{ab}}$ & $5.4 \pm 0.2^{b}$ & $5.5 \pm 0.5^{\mathrm{ab}}$ \\
\hline Albumin (g/dl) & $3.6 \pm 0.0^{\mathrm{a}}$ & $3.4 \pm 0.1^{\mathrm{ab}}$ & $3.5 \pm 0.3^{\mathrm{ab}}$ & $3.3 \pm 0.1^{b}$ & $3.1 \pm 0.1^{b}$ \\
\hline Urea $(g / d l)$ & $14.2 \pm 1.4^{\mathrm{a}}$ & $10.0 \pm 0.5^{b}$ & $12.5 \pm 2.5^{a b}$ & $8.1 \pm 0.3^{c}$ & $7.1 \pm 1.0^{\mathrm{bc}}$ \\
\hline Total cholesterol (mg/dl) & $89.7 \pm 5.5^{\mathrm{a}}$ & $59.0 \pm 8.7^{b}$ & $65.5 \pm 5.2^{\mathrm{b}}$ & $72.8 \pm 5.5^{\mathrm{ab}}$ & $48.2 \pm 3.0^{\mathrm{bc}}$ \\
\hline HDL cholesterol (mg/dl) & $40.0 \pm 12.2^{\mathrm{ab}}$ & $31.3 \pm 6.7 \mathrm{ab}$ & $51.8 \pm 9.4^{\mathrm{a}}$ & $43.7 \pm 4.4^{\mathrm{a}}$ & $26.7 \pm 3.0^{\mathrm{b}}$ \\
\hline Tri-glyceride (mg/dl) & $208 \pm 43^{a}$ & $152 \pm 40^{a b}$ & $72 \pm 22^{b}$ & $63 \pm 16^{b}$ & $40 \pm 0 c$ \\
\hline
\end{tabular}

A Values are means $\pm \mathrm{SE}$.

B abcMeans in the same row sharing a common superscript letter are not significantly different $(p<0.05)$.

ハク質レベルのときの血液性状は，5\%Fat 群および 30 \%Fat 群の值より低下する。一方, HPD 群のような 50 \% カゼインレベルであれば, 食事制限しない群 (5\% Fat 群, 30\%Fat 群）とほぼ等しい値を示す結果となっ た。

\section{要 約}

食事性肥満ラットにエネルギー制限食を与えたとき, タンパク質代謝への影響を検討した。

Sprague-Dawley 系雄ラットに高脂肪食 (30\%Fat 群) を投与し，対照群 (5\%Fat 群) とともに 12 週間飼育し た。12 週間後, 30\%Fat 群の体重が 5\%Fat 群よりも 有意に増加した。この食事性肥满ラットに 2 週間の食事 制限を行なった。すなわち，飼料摄取量を $5 \mathrm{~g} /$ 日に制限 し, 飼料中の脂肪含量は全群 $5 \%$ と一定で, $50 \%$ カゼ イン食群 (HPD), 25\% カゼイン食群 (SPD) および 5 \% カゼイン食群 (LPD) とした。2週間後, 体重はいず れも急激に約 $100 \mathrm{~g}$ 減少した。しかし摄取タンパク質レ ベルの違いによる体重減少への影響はなかった。

窒素出納は，5\%Fat 群より，30\%Fat 群が有意に高 く，また制限食の HPD 群および SPD 群では正の出納 を示したが，LPD 群で著しい負となった。

体組成のらち, 水分含量は各群間に有意差はなかった か，脂肪の割合は HPD 群かＳPD 群および LPD 群よ りも有意な低下を示し, タンパク質の割合は HPD 群が 有意に高くなった。

䀒組成では, 制限食群間にいずれも重量に差は認めら れなかったが，LPD 群は脂肪含量（\%)およびタンパ 重量は, 5\%Fat 群の値とほほ等しくなった。 血液性状においては，血墏中タンパク質港度は $5 \%$
Fat 群に比べ，HPD 群では差はなかったが，LPD 群が 有意に低下した。

以上のことより，各制限食での体重減少量は同程度で あったにもかかわらず， HPD 群では体脂肪だけが減少 し，体タンパク質および肝タンパク質が保持されていた ことから，制限食投与時の食餌中のタンパクレベルは， 体タンパク質代謝に大きな影響をもつといらことが考え られる。

本研究において, 肥満ラットの作成方法をご指導いた たきました国立栄養研究所の加賀綾子先生に深く感謝い たします。

\section{文献}

1) Garlick, P.J., Clugston, G.A.C. and Waterlow, J.C.: Am. J. Physiol., 238, E235 (1980)

2) Winterner, J., Bristrian, B.R., Bilmazese, C., Blackburn, G.L. and Young, V.R. : Metabolism, 29, 575 (1980)

3) Pencharz, P.B., Motil, K.J., Persons, H.G. and Duffy, B.J.: Clin. Sci., 59, 13 (1980)

4) Donald, P., Pitts, G.C., Pohl, S.L.: Science, 211, 9 (1980)

5) Swick, R.W. and Glibskov, C.L.: J. Nutr., 113, 2289 (1983)

6) Gurr, M.I., Mawson, R., Rothwell, N.J. and Steinberg, A.G.: J. Nutr., 110, 532 (1980)

7) McGovern, J.J., Jones, A.R. and Steinberg, A.G.: New Engl. J. Med., 253, 308 (1955)

8) Van Kampen, E.J. and Zilistria, W.G.: Clin. Chim. Acta, 6, 538 (1961)

9) Gornall, A.G., Bardawill, C.J. and Daid, M.M. : J. Biol. Chem., 177, 751 (1941)

10) Doumas, B.T., Watson, W.A. and Biggs, H.G. : Clin. Chim. Acta, 31, 87 (1971)

11) Kaplan, A.: Methods Biochem. Anal., 17, 311 
(1970)

12) Richmond, W.: Clin. Chem., 19, 1350 (1970)

13) Bucolo, G. and Daid, H. : Clin. Chem., 19, 476 (1973)

14) Folch, J., Lees, M. and Stanley, G.H.S.: $J$. Biol. Chem., 226, 497 (1957)

15) Tulp, O.L., Frink, R. and Danforth, E., Jr.: J. Nutr., 112, 2250 (1980)

16) Walks, D., Lavau, M., Presta, E., Yang, M. and Bjiornturp, P.: Am. J. Clin. Nutr., 37, 387 (1983)

17) Schmmel, R., Mickelesen, O. and Gill, J.L.: J. Nutr., 100, 1041 (1970)

18) Schmmel, R., Hu, D., Mickelesen, O. and
Romsos, D.R.: J. Nutr., 112, 223 (1982)

19) Abumrud, N.A., Stearns, S.B., Tepperman, H.M. and Tepperman, J.: J. Lipid. Res., 19, 423 (1978)

20) Brown, M.R., Klish, W.J., Hollander, J., Campbell, M.A. and Forbes, G.B.: Am. J. Clin. Nutr., 38, 20 (1983)

21) Fisler, J.S., Drenick, E.J., Blumfield, D.E. and Swendseid, M.E.: Am. J. Clin. Nutr., 35, 471 (1982)

22) Swick, R.W. and Gribskov, C.L. : J. Nutr., 113, 2289 (1983)

（昭和 61 年 6 月 19 日受理） 